\title{
Vulnerabilities and resilience in insurance investing: studying the COVID-19 pandemic
}

\author{
Patrick M. Liedtke ${ }^{1}$
}

Accepted: 24 February 2021 / Published online: 18 March 2021

(c) The Geneva Association 2021

\begin{abstract}
The COVID-19 crisis has major impacted the insurance industry in three dimensions: business operations, underwriting and claims and insurance investing. This paper will analyse the implications for insurance investing. We start by showing the impact of the severe drawdown in the equity markets during the initial phase of the crisis in March/April 2020 on a typical insurer's balance sheet. We then look at the effects of the dislocations in fixed income, which make up the largest share of exposures in insurance companies' portfolios. We track the performance of investment grade credit during the year while paying special attention to the impact of downgrades on insurers' solvency capital. We finally study alternative investments with particular focus on private markets. These investments are a faster-growing part of insurance companies' exposures and pose specific challenges as they are complex, more difficult to access, have limited liquidity and are often harder to price, especially during times of high market volatility. Yet, compared to their equivalent public market exposures, private investments provide additional income, which allows insurers to charge lower rates on their products to policyholders. As the sophistication and complexity of investments keep growing, companies as well as regulators need to find a good balance between policyholder protection and market efficiency.
\end{abstract}

Keywords Insurance $\cdot$ Investments $\cdot$ Drawdown · Downgrade $\cdot$ Regulatory capital · Solvency

\section{Introduction}

The COVID-19 crisis started in Wuhan, China in December 2019. However, it was not until it hit Italy a few weeks later, when the terrible images of the human loss of life it caused in Bergamo were transmitted on TV, that the world took notice.

Patrick M. Liedtke

patrick.liedtke@gmx.net

1 Department of Risk and Insurance, City University of London Business School, 106 Bunhill Row, London EC1Y 8TZ, United Kingdom 
Suddenly, it became clear that countries had to deal with a pandemic scenario of a magnitude not known since the Spanish Flu pandemic of 1918.

As a consequence of the virus spreading and governments and people reacting to it, the insurance industry was impacted on several fronts:

1. Impact on business operations:

Similar to other sectors of the economy, the insurance industry was affected by the direct consequences of its employees falling sick or staying home to care for sick relatives, by the travel and movement restrictions being put in place as lockdowns were introduced, and by the shift to remote working. This required a lot of attention to business processes, the welfare of staff and making sure that the orderly execution of client business could take place in an environment that had radically changed, practically overnight.

2. Impact on underwriting and claims:

Many insurance contracts directly or indirectly covered the risks associated with the pandemic. First, there was the direct impact of COVID-19 on morbidity and mortality as people fell sick and some of them died. At the same time, insurers were exposed via other lines of business outside of life and health insurance contracts (travel insurance, event cancellation, business interruption, etc). Insurers were thus exposed to sizeable payouts as claims started to materialise. Unfortunately, it quickly became clear that while the life and health claims could be handled fairly well given past experience and robust policy wordings, the same was not true with regard to the consequences of governmental decisions on the restrictions placed on businesses to operate. In many cases, insurance contracts were not as clearly defined as the contractual parties would have liked and a series of lawsuits triggered a wider legal discovery process that continues to this day and will do so for a protracted period. It stands to reason that, as on other occasions in the past, the industry will adapt and ultimately come up with improved contracts and specific solutions to the challenges posed by COVID- 19 .

3. Impact on insurance investing:

As one of the largest groups of institutional asset owners, the global insurance industry has total assets of well over USD 32 trillion (Statista 2020). ${ }^{1}$ The value of those assets was severely impacted by the crisis and even though markets recovered from their most stressful period in March 2020, the experience has left deep scars and raised many questions.

In this paper, we discuss some of the questions emanating from the crisis and the challenges facing the insurance industry, specifically in the area of investing. We start by showing the impact of the severe drawdown in the equity markets during the initial phase of the crisis in March/April 2020 on a typical insurer's balance sheet. We then look at the effects of the dislocations in fixed income, which make up the largest share of exposures in insurance companies' portfolios. We track the

\footnotetext{
1 See statista.com/statistics/421,217/assets-of-global-insurance-companies/.
} 
performance of investment grade (IG) credit during the year while paying special attention to the impact of downgrades on insurers' solvency capital. We finally study alternative investments with particular focus on private markets.

\section{Financial market background}

As the virus started to ravage social life and severely interrupted global business, financial markets reacted by contracting massively. As we will see below, an astonishing amount of equity market capitalisation was lost while fixed income markets seized up as interest rates became volatile and, especially in the U.S., dropped significantly.

When the Italian government confirmed the country's first case of the disease on 30 January 2020, one of the most-watched stock market indices, the American S\&P $500,{ }^{2}$ stood at 3284 . By 23 March, when the virus had been observed in most countries around the world and contact between people had been limited through a series of strict measures in response, it had fallen to 2237, a loss of $31.9 \%$.

However, the S\&P 500 in the U.S. was not alone. The world's leading major indices contracted from the end of January and hit their 2020 lows towards the end of March: the Nikkei 225 in Japan, the FTSE 100 in the U.K. and the CAC 40 in France each lost well over $40 \%$ during that period. ${ }^{3}$ These four markets alone- the U.S., Japan, the U.K. and France-represent together over $70 \%$ of world equity market value. ${ }^{4}$

In order to get a better understanding of how much such a drop in world equity markets is worth in dollar terms, we can infer from the market capitalisation of the indices how much wealth was destroyed. The S\&P 500 had a market capitalisation of about USD 26.72 trillion at the end of January 2020. So, the crisis had wiped out some USD 8.5 trillion from the leading companies in the U.S. market alone. SIFMA $^{5}$ valuations put the total world equity market value at the beginning of 2020 at USD 95.5 trillion. ${ }^{6}$ Hence, we can estimate that the global total loss in equity value at the trough would have been well over USD 30 trillion, a loss only comparable to that suffered during the Global Financial Crisis in 2008 and, in all likelihood, higher.

At the same time, the interest rate of the largest fixed income paper in the world, the 10-year U.S. treasury, collapsed from $1.6 \%$ to less than $0.6 \%$. It thus joined in one fell swoop the super low interest rate regime of other developed nations like Japan, Germany and other states in 'core' Europe (see Fig. 1). Italy experienced some remarkable interest rate volatility as long-term interest rates first increased to

\footnotetext{
${ }^{2}$ As per finance.yahoo.com/quote/^ ${ }^{\wedge} \mathrm{GSPC}$.

3 As per finance.yahoo.com/quote/.

4 See siblisresearch.com/data/us-stock-market-value/.

5 SIFMA is the U.S. trade association for broker-dealers, investment banks and asset managers operating in the U.S. and global capital markets.

${ }^{6}$ As per SIFMA Fact Book: sifma.org/resources/research/fact-book/.
}

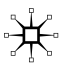


$1.8 \%$ as a reaction to market participants looking for what was at the time regarded as safer havens for euro-denominated government debt, notably Germany, and then fell during the remainder of the year to finish at $0.6 \%$, the lowest they have ever been.

These price movements are very important to all market participants. The global IG corporate bond markets are among the most important sources of funding for (particularly larger) corporations. At the same time, they provide investors steady sources of income at considerably lower risk than stock markets, ${ }^{7}$ while high-yield (HY) bond markets fall somewhere in between. ${ }^{8}$ More generally, however, lasting disruptions in debt markets and particularly persistent spikes in credit spreads are understood to have negative real effects as they are strongly associated with declines in future economic activity (see Gilchrist and Zakrajek 2012).

To insurance companies, changes in interest rates are particularly important as financial instruments that are directly exposed to them make up the majority of their balance sheets. As an illustration, Fig. 2 details the aggregate composition of European insurance companies' balance sheets as per EIOPA (2020c). (The picture is qualitatively similar in other regions of the world.)

The assets shown here depict the sum of investment assets held by European insurance companies, excluding assets held for index-linked and unit-linked contracts, reinsurance recoverables and short-term deposits. Government bonds and corporate bonds make up more than half the balance sheets by themselves. In addition, collective investment undertakings comprise funds that often contain bonds or other instruments with direct interest rate exposure of some kind. Similarly, holdings in related undertakings further expose insurance companies to bonds and mixed funds held at a subsidiary level. Adding to this the interest rate sensitivity of loans and mortgages, as well as structured notes, it becomes evident that the largest part of the insurance sector's exposure is dependent on and reacting strongly to interest rate changes. $^{9}$

While a negative interest rate shock, i.e. the downward correction of interest rates, might seem a positive event at first glance as it increases the value of the bonds (and similar fixed income assets), this is not so in the longer term. Insurance companies hold most of their fixed income assets to maturity and match them to their liabilities, so in most cases_at least as long as those assets and liabilities have

\footnotetext{
7 While default rates for bonds are generally lower than for equity investments and recovery rates are higher, the volatility of these financial instruments vary considerably over time as a function of supply, demand and a series of exogeneous factors such as monetary policy or regulatory intervention. Reilly et al. (2000, pp. 82-92) analyse the changing volatility of the government bond market over 50 years and examine how it compares to the volatility changes of the U.S. stock market. They conclude that the volatility of these two markets has differed dramatically over time.

8 The HY bond markets comprise bonds that are rated below IG. These are considered riskier as they are subject to higher (expected) default rates than IG bonds. See S\&P's discussion for a more detailed analysis of the (cor)relations between ratings, default rates and recoverables (S\&P Global Research 2018, 2019).

9 As Rajan (2005) discusses in his paper, portfolio allocation theory predicts that a fall in interest rate induces investors to shift away from those now lower-yielding safe assets and towards riskier ones. This in turn increases the riskiness of their portfolio. For financial institutions with fixed rate obligations, such as life insurance companies, the choice of risk taking is thought to reflect a 'search for yield' incentive, which encourages them to take on more risk as interest rates fall.
} 


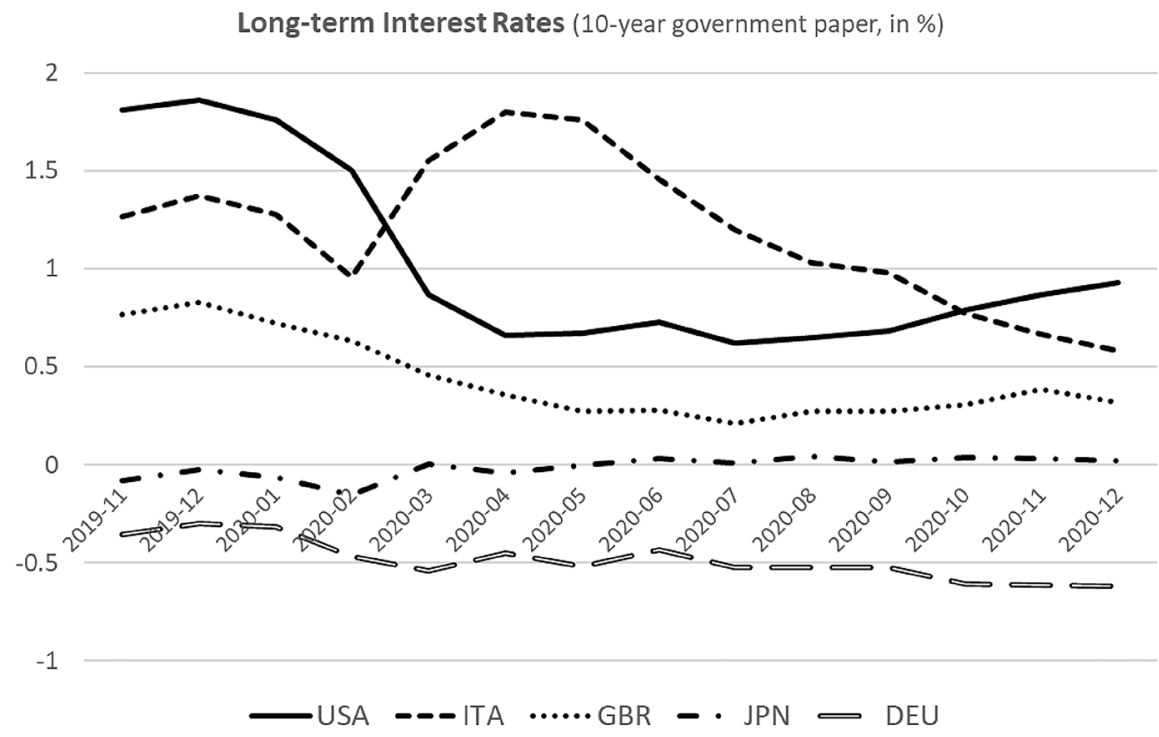

Fig. 1 Long-term interest rates. Source OECD data (extracted from data.oecd.org/interest/long-terminterest-rates.htm)

the same duration and move in log step—such a shock gets absorbed across the balance sheet. ${ }^{10}$ However, after the shock has occurred, insurance companies have to reinvest any new premium income at the new and now lower interest rate that the market offers. As a consequence, ceteris paribus, their future earnings will suffer. ${ }^{11}$

Insurance companies strive for income from their investments as it allows them to routinely service future claims, and investment income is an important element in the profitability of insurance undertakings. However, when it comes to the risk taking involved in searching for yield, the relations are mixed. On the one hand, their allocations to IG corporate bonds are multiple times larger than for sub-IG bonds. ${ }^{12}$ This is true in no small measure because of regulatory capital requirements, which become more demanding the longer the duration and the higher the riskiness of an asset. On the other hand, insurers look for additional income within risk (and rating) buckets. Becker and Ivashina (2013, p. 2) discuss this phenomenon, concluding "Consistent with lower rated bonds bearing higher capital requirement, insurance

\footnotetext{
10 An overview of the evolving investment strategies of insurers and the opportunities and constraints they face with respect to long-term investment activity can be found in Gründl et al. (2016).

11 There is an interesting discussion about real world market behaviour of participants who seem to be less influenced by absolute interest rates than theory might suggest. See Sharpe and Suarez (2014).

12 See EIOPA insurance portfolio data for Q1/2020 (EIOPA 2020a) as per www.eiopa.europa.eu/toolsand-data/insurance-statistics_en.
} 

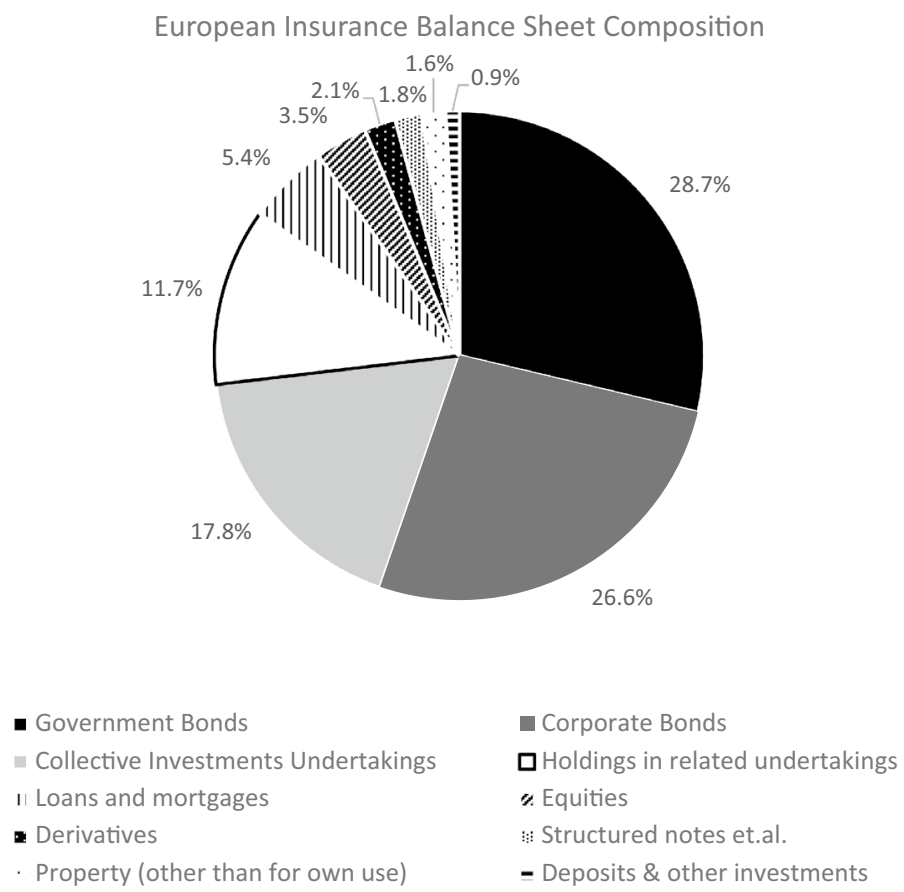

Fig. 2 European insurance companiees' balance sheet composition. Source EIOPA (2020c), data for Q1/2020

firms' prefer to hold higher rated bonds. However, conditional on credit ratings, insurance portfolios are systematically biased toward higher yield".

During the COVID-19 crisis, insurance balance sheets came under pressure not only because of rising rates (see above) but also because rolling over investments became increasingly difficult. An absence of market liquidity and the consequences of a herd effect driving investors towards lower-risk assets in sectors that were considered safer made trading these assets extremely expensive-if possible at all. This strained market situation drove bid-ask spreads from their normal range to historic highs and made portfolio adjustments more difficult. Sectors that were directly exposed to the consequences of the new virus restrictions, such as airlines, tourism, hospitality etc., ${ }^{13}$ immediately dropped out of favour to be replaced by a particularly strong showing of the tech sector, the health industry and everything connected to remote working and remote entertainment.

Such profound changes are not without consequence and we will discuss some of them in greater detail below.

\footnotetext{
${ }^{13}$ In September 2020, S\&P listed the following five industries as most impacted by the COVID crisis, based on increased default risk: airlines, leisure facilities, restaurants, oil \& gas drilling and auto parts \& equipment. See spglobal.com/marketintelligence/en/news-insights/blog/industries-most-and-least-impac ted-by-covid19-from-a-probability-of-default-perspective-september-2020-update.
} 


\section{Fixed income}

As we saw earlier, fixed income investments are the core of the assets that insurance companies hold to satisfy future liabilities. However, a long-term trend towards ever lower interest rates has impacted the ability to derive much future income from those assets. If we estimate that typically over $75 \%$ of an insurance balance sheet generates cash flow out of fixed income exposures, it quickly becomes clear that the industry is facing a major problem. This problem has been recognised by experts in the industry for a long time, but the fact that the 10-year U.S. treasury fell to below $1 \%$ moved the world's largest capital market, the U.S., in line with other developed regions that had experienced low to even negative interest rates (such as Germany) for several years already. This was a game changer. No longer could investors in other markets look to the U.S. to find yield. American companies now have to employ the same techniques to create better income streams out of other types of investments than the safe U.S. government bonds and USD investment-grade corporate bonds they used to buy.

One answer to an absence of future income in safe, i.e. IG, instruments is to go down the risk curve. ${ }^{14}$ However, this is not something that comes for free, as capital costs under risk-based capital systems, such as used by the NAIC in the U.S. or EIOPA (and the British PRA) in Europe, scale up as the riskiness of assets increase. Table 1, which details the capital that must be held by European insurers employing the standard model under Solvency II, illustrates this.

While the downgrade of a five-year duration security from AA to A increases the solvency capital requirement by an extra $1.5 \%$, this differential jumps to $10 \%$ in the case of a downgrade from BBB (the lowest IG rating) to BB (the first HY rating). In the case of a 10-year bond this effect is similar, if at a higher level due to the greater duration of the security: the differential increases from 2\% (AA to A downgrade) to a whopping $15 \%$ (BBB to BB). As becomes apparent from Table 1, any downgrade puts considerable strain on the capital position of insurance companies. This strain is exactly what had insurance supervisors worried last year.

How large are the IG markets? In December 2019, the EUR IG market was worth some EUR 2.62 trillion, with $10.8 \%$ of the securities or EUR 283 billion rated at BBB-, i.e. just one notch above the capital-intensive HY zone. The equivalent data for the USD market was even more alarming: $13.4 \%$ of the USD 7.31 trillion IG

\footnotetext{
14 As Longstaff et al. (2007) write, most of the variation in yields across corporate bonds is related to credit risk. So, if companies want to achieve higher yields, they will generally have to accept higher credit risk, which has the impact on regulatory capital we discuss below. While an investor would expect price differentiation for otherwise similar bonds to occur if their liquidity in the secondary market is lower, this seems to have less of an impact, as Becker and Ivashina (2013, p. 3) assert. From an insurance perspective, this makes sense as insurers tend to acquire their assets in the primary market and often hold them to maturity without any trading during their lifetimes.
} 
market was rated BBB- going into the crisis, i.e. in the U.S., USD 980 billion was at risk of falling into high yield.

The regulatory capital effect of what was happening was not all that had supervisors worried. Besides the capital impact, there is also an economic effect when securities suffer downgrades: the price of a security correlates inversely with its riskiness. So, a drop in credit rating, which reflects an increase in riskiness, almost always leads to a depreciation of the security. Suddenly, insurance companies were confronted with a double whammy. Downgraded paper in their books not only required more regulatory capital to be held against it-it also lost market value. The exact impact of this with regard to financial results in the short term is highly dependent on the accounting regime the company uses and whether any mechanisms are used that decouple short-term price fluctuations from the bottom line (such as the matching adjustment mechanism). However, in a full mark-to-market environment, the impact for the company would be financially negative and show up immediately, thus weakening its capital position further.

In order to gain insight into the magnitude of the problem and how stressful markets were for insurance companies, we need to look at the credit downgrades during the first half of 2020. Table 2 shows the share of downgrades as a proportion of the EUR IG market, the GBP IG market and the USD IG market. It compares what happened during the months March to May 2020 with the long-term average of downgrades from the years 1981 to 2019. According to S\&P, the global corporate downgrade average - which would include not only the IG markets but crucially also the $\mathrm{HY}$ and emerging corporate markets, which are typically prone to substantially more downgrades than the IG market-was $11.7 \%$. $^{15}$

The data in Table 2 show how precarious the situation was in early June 2020, when the three IG markets had not only overshot the average downgrade of the prior ca. 30 years, but were on track to beat the worst year on record for that period, 2002, when a full $19.2 \%$ of securities were downgraded.

Luckily, the situation then changed as the various counter measures against the virus spread showed results and strongly accommodative monetary policy action and fiscal stimulus packages helped the nervous markets to settle. Following June 2020, there were hardly any further downgrades and the year 2020 finished not only with record-breaking downgrades but just slightly over or at the long-term average: $13.3 \%$ downgrades in EUR IG, $11.8 \%$ in USD IG and $11.6 \%$ in GBP IG.

The downgrading crisis in 2020 was averted, but a more fundamental question begs to be asked. During the major part of the crisis, insurers had to battle two fronts simultaneously: digesting the immediate economic impact of any downgrades as well as satisfying the growing need for regulatory capital. It seems that risk-based capital systems are exerting twice the pressure at times of crisis. Is that really in the interest of efficient capital markets?

To illustrate the point-scared by the effects of the downgrade phenomenon, even well-capitalised insurers stayed away from the market. Instead of using their strong balance sheets to buy into weaker markets and hence provide a counterbalance to

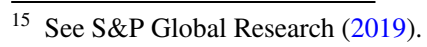


Table 1 Regulatory capital charge under Solvency II (standard capital model). Source EIOPA

\begin{tabular}{lcc}
\hline Credit rating & $\begin{array}{l}\text { Solvency capital charge (5-year modified } \\
\text { duration) }(\%)\end{array}$ & $\begin{array}{l}\text { Solvency capital charge (10- } \\
\text { year modified duration) }(\%)\end{array}$ \\
\hline AAA & 4.5 & 7.0 \\
AA & 5.5 & 8.5 \\
A & 7.0 & 10.5 \\
BBB & 12.5 & 20.0 \\
BB & 22.5 & 35.0 \\
B or lower & 37.5 & 58.5 \\
\hline
\end{tabular}

more fragile players who had to sell securities at risk of downgrade (especially if they were BBB-rated), they actually acted procyclically by selling particularly endangered securities when those were already under pressure.

One has to remember that insurance companies, for the most part, hold securities to maturity and a downgrade per se does not automatically mean that the principal is at risk of default. According to S\&P's analysis (S\&P Global Research 2019), the average default rate of an A-rated (BBB-rated) security is $0 \%$ (1.3\%) over a one-year horizon and $0.8 \%(4.2 \%)$ over a five-year horizon. Downgrading a security three notches (and not just one) from an AA rating to an A rating, has no impact on its default rate over a one-year time horizon; it stays at exactly 0. Downgrading it three notches from $\mathrm{A}$ to $\mathrm{BBB}$ raises the default rate by $1.3 \%$. Over a five-year time horizon, the difference in moving from $\mathrm{A}$ to $\mathrm{BBB}$ is more pronounced at a $3.4 \%$ higher default rate.

Let's consider the prospective recovery rate of such a default, which in Europe has been at an average of $72.7 \%$ during the years 2003 to 2019 (S\&P Global Research 2020). Hence, a $3.6 \%$ increase in default probability would be equivalent to a $2.5 \%$ increase in expected loss. Now compare this to the capital charge on a bond with five-year (modified) duration, which increases from $7 \%$ to $12.5 \%$ as it moves from being A-rated to being BBB-rated. ${ }^{16}$

The second question pertains to the concerns surrounding cliff-edge effects for the so-called 'fallen angels', i.e. securities whose rating migrates from IG to HY as part of a downgrade. The issue was intensely discussed in May and June 2020 when a scenario of massive downgrade migration of credit from IG to HY was contemplated around the world. Insurance companies were deemed to be potential

\footnotetext{
16 EIOPA also discusses the effects of bond downgrades (EIOPA 2020b). See eiopa.europa.eu/sites/ default/files/financial_stability/eiopa-financial-stability-report-july-2020.pdf. EIOPA makes the point that solvency capital effects would be mitigated by loss-absorbing mechanisms, citing profit-sharing mechanisms and the volatility adjustment. However, profit sharing exists only for certain products (in life insurance) while volatility adjustment is only used by some insurance companies. In its example, based on the standard formula, the downgrade of BBB-rated paper to HY would increase the shock factor used to calculate the spread risk from $12.4 \%$ to $18.8 \%$, which, incorporating assumptions about diversification effects within the market risk module, would become $6.7 \%$ and $10.3 \%$, respectively. As this increase is somewhat offset by the fall in market value of the bonds, it is found that the SCR spread risk charge could increase by around $6 \%$ in this hypothetical scenario.
} 
Table 2 Downgrades of the given security basket (in \%). Source Bloomberg, S\&P, Moody's, Fitch

\begin{tabular}{llll}
\hline & $\begin{array}{l}\text { EUR investment } \\
\text { grade (\%) }\end{array}$ & $\begin{array}{l}\text { GBP investment } \\
\text { grade }(\%)\end{array}$ & $\begin{array}{l}\text { USD invest- } \\
\text { ment grade } \\
(\%)\end{array}$ \\
\hline March 2020 & 5.5 & 4 & 5.5 \\
March (average year 1981-2019) & 2.9 & 2.9 & 2.9 \\
April 2020 & 8.5 & 5 & 8 \\
April (average year 1981-2019) & 3.9 & 3.9 & 3.9 \\
May 2020 & 11 & 8 & 10 \\
May (average year 1981-2019) & 4.9 & 4.9 & 4.9 \\
\hline
\end{tabular}

The ratings shown makes use of the Bloomberg Barclays methodology, which uses the second-worst rating from the three leading rating agencies: S\&P, Moody's and Fitch

For illustrative purposes, we use a linear distribution during the year of the average overall proportion of downgrades equivalent to $11.7 \%$ divided by 12 months

accelerators of such a movement as they would try to avoid the double whammy of economic loss and the regulatory capital impact mentioned above.

We analysed the cliff-edge phenomenon in a BlackRock paper and came to the conclusion that it had not materialised (Novick et al. 2020). ${ }^{17}$ Comparing the dynamics for fallen angels during the Global Financial Crisis of 2008 and the situation in 2020, it was notable that in both cases there were no cliff-edge effects. The reason for this is that insurance companies are more patient and defensive, tending to hold on to their investments rather than trying to sell them into a falling market. It also became clear that even during a crisis with a sharp market reaction, such as in 2020, downgrades take some time to materialise and the effects are digested over weeks in the market. While the spreads for fallen angels rose more sharply in 2020 and over a shorter time period than during other crises, price adjustments did not take place in one go. Our conclusion was that "Experience shows price adjustment to downgrades is a process, not an event, and begins prior to 'downgrade day' as bonds are placed on 'negative outlook' or 'negative watch', and the market absorbs information on company prospects. Cliff edge effects around the downgrade itself are prevented through flexibility in investors' mandates, and less constrained investors spotting attractive opportunities in downgraded bonds" (Novick et al. 2020).

\section{Alternative investments and private markets}

Insurers have been confronted with falling interest rates for a long time, but as the rates for many government bonds have reached zero, or indeed turned negative, the necessity of finding alternative investments has become even more important. One

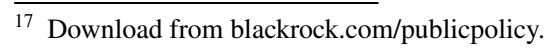


solution has been the adoption of private market assets. These assets are attractive as they can satisfy the need for higher returns and provide some diversification, thus providing greater portfolio resilience. In certain cases, there is also attractive regulatory capital treatment, which means that regulatory capital costs can be lower than for exposures in more traditional asset classes. ${ }^{18}$

However, private market assets function differently to the traditional public markets in debt and equity that insurers are used to. To start with, there are no readily available markets that regularly place new issuances nor are there necessarily open and widely transparent price-setting mechanisms. Private assets cannot be bought immediately and rather than executing trades on a computer screen, they need to be sourced. This means that the buyer usually makes an upfront capital commitment to a specialised manager, who in turn works to secure deals that provide the assets that fulfil the purchase agreement. While the purchase agreements have some leeway in terms of what assets can be sourced, insurers tend to be selective, as they generally prefer high-quality investments, ${ }^{19}$ while trying to avoid risk aggregation across their balance sheet. $^{20}$

Once a mandate is established and the manager starts sourcing assets, the committed capital is then drawn. However, as the timing and volume of deals are subject to significant uncertainty, the investment process is much less predictable than in public markets. Another limitation arises from the fact that once invested, capital cannot be readily withdrawn. As no public markets exist for the assets and standardised formats are rare, any transaction to transfer a private asset from one owner to the next is onerous and slow. It requires longer and more involved due diligence and greater scrutiny by all parties involved, hence private assets are transferred more seldomly than public assets. Insurers must therefore not only consider the funding of any capital calls carefully but also how to deal with capital returns and any unforeseen events. As a consequence, liquidity management is more complex and involves greater uncertainty.

As the proportion of private assets increases in insurers' portfolios, supervisors pay closer attention to how they manage the aforementioned risks. Liquidity concerns in particular play a substantial role, not least because the absence of liquidity during the COVID-19 crisis in 2020 exacerbates the situation where insurers hold more assets that exhibit by their very nature lower liquidity, such as private assets. In its statement from July 2020, "EIOPA supports the views expressed by the European

\footnotetext{
18 One such example is the capital charge levied under Solvency II for certain infrastructure assets, which is lowered if they qualify for that special treatment. The equity risk charges for qualifying infrastructure equity investments are set out in Article 169 Paragraphs 3 and 4 of Commission Delegated Regulation (EU) 2015/35.

19 Private assets are subject to the same risk-based capital requirements as public assets; hence, they share the same correlation between riskiness and capital requirements as discussed earlier in this paper.

20 Risk aggregation across the balance sheet can occur when assets are exposed to the same risks as the liabilities that an insurer already owns. An obvious example is that an insurance company would not want to invest in a toll bridge as part of an infrastructure deal when it is at the same time the insurer of said bridge through an insurance contract. In case of an event destroying the bridge, the insurance company would not only have to pay out on the insurance contract but also suffer the loss of an asset on its balance sheet.
} 
Systemic Risk Board (ESRB) regarding the importance of improving the monitoring of liquidity risks in the insurance sector with the aim to enhance Europe's preparedness to potential future shocks" (EIOPA 2020c). While private assets are harder to access and more involved to manage, they generally provide better returns and, in the case of debt instrument, higher yields. Insurance companies welcome the additional income stream and, as sophisticated investors across a broad spectrum of assets, they have steadily increased their exposure to private assets. Research firm Cerulli states in its latest press release, "Although the pandemic is likely to negatively impact 2020-year-end fundraising, the attractive attributes that private infrastructure offers investors will drive assets under management to higher levels and new strategies will proliferate" (Cerulli Edge 2020).

Many private assets, but especially those in infrastructure, are supported by supervisory authorities. The NAIC writes, "There is a huge funding gap between what is required to support infrastructure going forward and what is available in the U.S. as well as all over the world. In the United States, the funding gap is estimated at about \$2.1 trillion over the ten years from 2016 to 2015, at the same time, simply updating and maintain existing infrastructure networks and systems would require another \$1 trillion” (NAIC 2020).

It seems that there is a growing market for private assets, but as insurers have come to depend more and more on them for achieving their portfolio returns, the ability to incorporate private market assets into insurers' portfolio construction frameworks moves centre stage. This includes not only the aforementioned liquidity management but also overcoming challenges such as forming robust views on expected return assumptions, accounting for a wider dispersion of outcomes and considering the accounting and tax treatment of such assets.

In its Q2/2020 model portfolio analysis, EIOPA estimates that European life insurance companies (excluding unit-linked business) hold about $8 \%$ alternative assets, while non-life companies hold about $11 \%{ }^{21}$ While a global allocation of ca. $10 \%$ to alternative assets would equal about USD 3.2 trillion for the insurance industry, it is the growth potential that has many providers fascinated. Alternatives specialist firm Preqin postulates, "We expect AUM growth in alternative assets to average $9.8 \%$ per year to 2025. Persistently low interest rates will attract investors of all types drawn to the promise of outperformance, diversification, and lower correlation with public markets." 22 According to their calculations, the global alternative asset base under management will grow from USD 10.7 trillion in 2020 to USD 17.2 trillion in 2025 .

It seems inevitable that insurance companies will play a major role in this development, thus increasing further the complexity and sophistication of their balance sheets. This will require more data, better portfolio management, more highlytrained investment specialists and rigorous risk management. The question is: how well will the industry cope with these demands when it is challenged on so many other fronts, too?

\footnotetext{
21 See eiopa.europa.eu/tools-and-data/insurance-statistics_en.

22 As per preqin.com/future.
} 


\section{Outlook}

Insurance companies are not only one of the largest groups of institutional investors, they are also one of the most sophisticated. The strict and multifaceted rules that govern their investment decisions, the complex interactions between their liabilities and their assets, and their general predilection towards capital preservation (particularly under adverse conditions) pose specific demands, especially during times of crisis. As we expect the complexity and sophistication to grow, insurance professionals and regulators will have to balance policyholder protection with portfolio productivity to guarantee vibrant insurance markets. Studying the effects of the COVID-19 crisis on insurance balance sheets should provide insights that will help the industry to effectively evolve its regulatory regime while still taking advantage of the increasingly broader opportunity set in the markets.

$* * * * *$

\section{Post scriptum}

This paper is written in honour of my friend and mentor Orio Giarini, who passed away on Friday, 28 February 2020 in Trieste, Italy, at the age of 84.

Orio and I spoke for the first time in the summer of 1995 following our introduction by a mutual friend. He was looking for somebody "young, smart and intellectually curious", as he put it, to run an international research project on the future of work and retirement for the Club of Rome, where he was an Executive Board Member. At the time, I was running my independent macroeconomic research bureau in Frankfurt, Germany, and thus had much flexibility to take on projects. So, after some correspondence, I boarded a flight to Geneva to meet with Orio. What in my mind had meant to be a formal interview turned into a full day of intellectually stimulating exchanges of ideas and concepts. As it grew later in the day, Orio proposed that we should move from his office, where he worked as the Secretary General of The Geneva Association, to his private place. This was in Ivoire, a romantic if somewhat sleepy medieval town on the southern shore of Lake Geneva, half an hour away by car. There, we ended up sitting on his balcony, exchanging more ideas while sipping a Burgundy red and looking at the sun setting behind the Jura mountains. It was then that he asked me whether I wanted to lead the research project that eventually became our joint book on the future of work. How could I refuse him? It subsequently turned out to be one of the best decisions of my life. The project became a report to the Club of Rome, turned into an economic bestseller and was translated into nine languages.

Orio later introduced me to the insurance CEOs that made up the membership of The Geneva Association and offered me another job, first as his Delegate, later as his Deputy and in June 2000 I was elected by the insurance CEOs as 
Secretary General, thus becoming his successor as he retired. Partially retired, as he was always keen to point out, and keeping himself busy intellectually with an unrivalled network of experts around the globe. In his partial retirement he moved to his birth town Trieste, where he founded the Risk Institute. He then set up the European Papers on the New Welfare and became a Trustee of the World Academy of Art and Science. He promoted the Cadmus journal and kept writing articles about economics, retirement, the new welfare state and risk issues in the modern world. He lived his own paradigm of gradual retirement and went on trying to understand the world and explaining it to others until his death.

Orio was an intellectual giant, but a very special one. Even though he was a professor at the University of Geneva and had published over 10 books and countless articles and scientific papers, he did not fit the traditional mould of an academic. It was Orio who conceived the idea, together with Fabio Padoa Schioppa, then Chairman of Generali, Raymond Barre, the former Prime Minister of France, and a small group of international insurance executives, to establish a think tank devoted to the study of risk and insurance. In 1973, this became the International Association for the Study of Insurance Economics, or by its shorter name, The Geneva Association. He led the organisation for 27 years until the year 2000. He was uniquely suited to the task: intellectually very curious, with great creativity and a healthy dose of diplomatic charm, he could bridge the gap between the demanding leaders of the world's largest insurance companies and the world of academia and research. He had honed his skills early in his professional life, first as a passionate European federalist, then as a researcher at the Batelle Institute.

At the same time, Orio loved the good life: he enjoyed good food, good wine and always a good conversation. There was hardly a country in the world where he had not made a friend, hardly a major city where he had not given a speech, and hardly a beautiful place he had not visited. He would know the finest hotels and the most hidden gems among the little restaurants out there. He was extremely generous and shared all of it with his friends. He would impart his wisdom freely but could listen as well. He was faithful and trustworthy, but also funny and eloquent. Orio and I shared a joint office for many years and went on countless trips together, yet I was never once bored. He always had something interesting to think and talk about.

Orio was as close to me as an intellectual father could ever be. And I will always miss him as much. Thank you, Orio, for everything!

\section{References}

Becker, B., and V. Ivashina. 2013. Reaching for yield in the bond market. NBER Working Paper No. 18909.

Cerulli Edge. 2020. Cerulli research report on U.S. asset and wealth management, edition 2020.

EIOPA. 2020a. Insurance portfolio data for Q1/2020. www.eiopa.europa.eu/tools-and-data/insurancestatistics_en.

EIOPA. 2020b. EIOPA financial stability report, July 2020. eiopa.europa.eu/sites/default/files/financial_ stability/eiopa-financial-stability-report-july-2020.pdf. 
EIOPA. 2020c. EIOPA supports ESRB call enhanced monitoring liquidity risks insurance sector. 9 July 2020. eiopa.europa.eu/content/eiopa-supports-esrb-call-enhanced-monitoring-liquidity-risks-insur ance-sector_en.

EU Commission. 2015. EU Commission Delegated Regulation (EU) 2015/35. eur-lex.europa.eu/legalcontent/EN/TXT/PDF/?uri=CELEX:32015R0035\&from=EN.

Gilchrist, S., and E. Zakrajek. 2012. Credit spreads and business cycle fluctuations. American Economic Review 102 (4): 1692-1720.

Gründl, H., M. Dong, and J. Gal. 2016. The evolution of insurer portfolio investment strategies for longterm investing. OECD Journal: Financial Market Trends 2016 (1).

Longstaff, F., S. Mithal, and E. Neis. 2007. Corporate yield spreads: Default risk or liquidity? New evidence from the credit default swap market. Journal of Finance 60 (5): 2213-2253.

NAIC. 2020. Infrastructure investments. content.naic.org/cipr_topics/topic_infrastructure_investments. htm. Accessed 30 Nov 2020.

Novick, B., J. Cound, P. Liedtke, P. Le Bihan, S. Asba, and A. Jackson. 2020. Lessons from COVID-19: European BBB bonds and fallen angels. blackrock.com/publicpolicy.

Preqin. 2020. The future of alternatives 2025. preqin.com/future.

Rajan, R.G. 2005. Has financial development made the world riskier? NBER Working Paper No. 11728.

Reilly, F., D. Wright, and K. Chan. 2000. Bond market volatility compared to stock market volatility. The Journal of Portfolio Management 27 (1): 82-92.

S\&P Global Research. 2018. Default, transition, and recovery: 2018 annual global corporate default and rating transition studies.

S\&P Global Research. 2019. Default, transition, and recovery: 2019 annual global corporate default and rating transition studies.

S\&P Global Research. 2020. European corporate recoveries over 2003-2019, the calm before the covid19 storm. spglobal.com/ratings/en/research/articles/200805-european-corporate-recoveries-over2003-2019-the-calm-before-the-covid-19-storm-11559269.

Sharpe, S., and G. Suarez. 2014. The insensitivity of investment to interest rates: Evidence from a survey of CFOs. Federal Reserve Board Finance and Economics Discussion Series, 2014-02.

SIFMA. 2020. SIFMA fact book. sifma.org/resources/research/fact-book/.

Statista. 2020. Total assets of insurance companies worldwide from 2002 to 2018. statista.com/statistics/ 421217/assets-of-global-insurance-companies/.

Publisher's Note Springer Nature remains neutral with regard to jurisdictional claims in published maps and institutional affiliations.

\section{About the author}

Patrick M. Liedtke is Honorary Visiting Professor at the City University London's Business School for Risk and Insurance and a leader of the global insurance practice at BlackRock. He was the Secretary General of The Geneva Association from 2000 to 2012. 